SUSTAINABLE FORESTRY

COLLECTION 81-82, 2020
ODRŽIVO ŠUMARSTVO

ZBORNIK RADOVA 81-82, 2020

UDK 630*4:502.175(497.11)=111

Original scientific paper

\title{
FOREST ECOSYSTEMS VITALITY MONITORING (ICP FORESTS, LEVEL I) WITH SPECIAL EMPHASIS TO THE AFFECTED PART OF THE SAMPLE TREES IN THE REPUBLIC OF SERBIA
}

\author{
Renata GAGIĆ-SERDAR ${ }^{l}$, Tomislav STEFANOVIĆl , Ilija ĐORDEVIĆ', \\ Goran $\check{C} E \check{S} L J A R^{l}$, Miroslava MARKOVIĆ , Natalija MOMIROVIĆ $^{l}$
}

\begin{abstract}
Trees condition on the sample plots of the ICP forests, Level I, is especially considered and monitored by the typically damaged and affected part of the tree on which it occurs. Due to the need to enter unique data for the measured parameters (visible damages), their codes are assigned for each damage. These are the results from Sample plots, Level I, based on the ICP methodology. The results are entered into a single database for all participating countries. Infested assimilation organs - leaves or needles are direct indicators of the condition of the trees. The most common damage to leaves is caused by miners, gnats, beetles, and insects that totally bite the leaves so parts of the leaves are completely missing (Lymantria dispar L.). The leaves are mined by Stigmellidae, Gracillariidae, Cynipidae forming galls; there are also damages from the early oak defoliators Geometridae and Tortricidae. Apart from defoliators, the most common are xylophagous insects (for example, bark beetles) as well as root pests.

The fungi that most commonly occur on the leaves are oak powdery mildew (Erysiphe alphitoides) and Rhytisma acerinum (which attacks species of the genus Acer). Other damages that occur are verticillium wilt (diseases of the conducting vessels), beech bark disease, then rot of the appendix, trunk, and branches. The paper presents the observed damage and diseases on the experimental plots of the ICP forests, Level I, in Serbia, according to the parts of the tree where they were discovered.
\end{abstract}

Keywords: harmful insects, trunk, diseases, forest condition assessment, ICP sample plots

\footnotetext{
${ }^{1}$ Institute of Forestry, Kneza Višeslava 3,Belgrade, Serbia

Corresponding author; e-mail: katas96@hotmail.com
} 


\section{MONITORING VITALNOSTI ŠUMSKIH EKOSISTEMA (ICP ŠUME, NIVO I) SA POSEBNIM OSVRTOM NA OŠTEĆENI DEO STABLA U REPUBLICI SRBIJI}

Izvod: Kondiciono stanje drveća na oglednim parcelama ICP šume, Nivo 1 posebno razmatra $i$ prati tipski oštećeni $i$ zahvaćeni deo stabla na kojem se javlja. Zbog potrebe unošenja jedinstvenih podataka za izmerene parametre (vidljiva oštećenja), njihovi kodovi se dodeljuju za svako oštećenje. Ovo su rezultati sa oglednih površine prvog nivoa na osnovu ICP metodologije. Rezultati su uneti u jedinstvenu bazu podataka za sve države koje učestvuju. Napadnuti asimilacioni organi - list ili iglice direktni su pokazatelji kondicionog stanja drveća. Najčešće štete na lišću izazivaju mineri, galaši, savijači i insekti koji totalno izgrizaju lišće te potpuno odsustvuju delovi listova (Lymantria dispar L.). Lišće miniraju Stigmellidae, Gracillaridae; Cynipidae stvaraju gale; tu su zatim oštećenja od ranih hrastovih defolijatora Geometridae i Tortricidae. Pored defolijatora najzastupljeniji su ksilofagni insekti (na primer potkornjaci) kao i štetočine korena.

Gljive koja se najčešće javljaju na lišću su hrastova pepelnica (Erysiphe alphitoides) $i$ Rhytisma acerinum (koja napada vrste roda Acer). Ostala oštećenja koja se javljaju su verticilioze (bolesti sprovodnih sudova), bolest kore bukve, zatim trulež pridanka, debla i grana.

U radu su prikazana oštećenja i bolesti na oglednim parcelama ICP šume Nivoa I u Srbiji, prema delovima stabla na kojima su otkrivena.

Ključne reči: štetni insekti, deblo, bolesti, procena stanja šuma, ICP ogledne parcele

\section{INTRODUCTION}

The Ministry of Agriculture, Forestry and Water Management of the Republic of Serbia - Directorate of Forests assigned the tasks of coordination and management of the programme ICP Forests to the Institute of Forestry - National Focal Centre of the Republic of Serbia. This paper aims to present the total survey analysis of the affected tree part and the results of last year's research, which is based on forest condition monitoring in the Republic of Serbia.

In this article, we focus on tree condition as measured by, affected tree part connected often with the degree of defoliation (needle loss), affecting the tree on sample plots in Serbia. We surveyed the regional distribution of tree health, with an extensive monitoring network, in Serbia, to answer the following questions:

(1) How large is the annual variation in defoliation between plots and within plots over years (i.e., plot $\times y e a r \times$ affected tree part interaction)?

(2) What is the relative contribution of affected tree part between the species to the variation and tree defoliation levels?

(3) How useful/sensitive are extensive tree health monitoring networks to reveal the impacts of widespread leaf/needle loss?

Country Serbia has its unique country code, number 67, based on the disposition of the countries participating in ICP programme. In 2003, after the study of the procedure of forest condition monitoring based on ICP methodology (Ferretti $\&$ Chiarucci, 2003), the training course was organised at the Institute of Forestry, for the experts selected to perform the crown condition assessment. In collaboration with 
the Institute of Lowland Forestry and Environment, 103 sample plots in 16 x16 km grid were reconstructed and the crown condition of forest trees was assessed. In the area of Serbia (without Kosovo and Metohija) it was necessary to revise the old plots according to the Level I cooperative programme (Stefanović et al, 2003), as well as the control and harmonisation with the installed coordinate network at the level of Europe. NFC of Serbia also carried out the entry and application of the reconstructed sample plots in the GIS (Geographic Information System) Database (Nevenic, 2008). In 2004, it was concluded that the reconstructed 103 sample plots did not represent fully the status of vegetation cover in Serbia so that additional 20 sample plots were selected and installed on the area of central Serbia, and 7 new plots in Vojvodina. The total number of installed sample plots in the Republic of Serbia was then 130 sample plots. The Institute of Forestry, in collaboration with the Institute of Lowland Forestry and Environment, carries out the monitoring and assessment of the forest health status on the territory of Serbia. In 2004, the more in-depth monitoring of forest tree diseases and soil chemistry on additional 20 sample plots was realised by the Faculty of Forestry in Belgrade. The analysis of 106 samples of forest nutrition were analysed in the laboratories of the Institute of Forestry (43 samples) and the Faculty of Forestry (63 samples). The GIS database in NFC of Serbia was updated for the additional 20 new plots (Nevenic, 2009).

In 2020, the activities on forest condition monitoring were continued in Serbia on 130 sample plots.

\section{METHODS AND CRITERIA}

This research has been done according to the ICP Forests Methodology. In 2020, the activities on forest condition monitoring were continued in Serbia on 130 sample plots. A sample plot is spatially determined by a coordinate grid of sample plots. It is marked with a brightly colored metal stake driven in the center. The sample trees for crown condition assessment are selected systematically as a 4-point cluster. Oriented along with the main compass directions at a distance of $25 \mathrm{~m}$ from the grid point - stake, the 6 trees ( 24 sample trees per plot) nearest to the subplot center are selected as sample trees. The tree sample includes all tree species, provided the trees have a minimum height of $60 \mathrm{~cm}$. The trees selected for assessment are classified according to crown canopy classes after Kraft (dominant, codominant, subdominant, sup-pressed, dying), but they must be without significant mechanical damage. The selected trees are permanently marked by numbers for future permanent assessment. The trees removed by management operations or for other reasons are replaced by the newly selected trees. If the stand is removed by clear-felling, the grid point should be kept till the establishment of the new stand. Within the national and transnational survey (Level I) crown condition is expressed by the classes of defoliation, discoloration, and combined damage classes (Seidling $\&$ Mues, 2005). Defoliation is assessed in 5\% steps and it is grouped in 5 classes of unequal extent.

New is categoriation by affected tree part which is damaged by different factors in 2020. According to the part of the plant (tree) on which the damage appears on the following charts, the participation of the affected plant organs is given. 
Leaves or needles with conifers, ie. the assimilation mass of the canopy itself is most massively endangered by various pathogens and insect pests of forest trees. The conclusion is that the leaf mass is the most endangered, but also the most sensitive part of the plant crucial for survival, the growth and the condition itself depends on it.

\section{RESULTS}

During this year, the defoliation of Norway spruce and black pine has remained quite constant, while the defoliation of Scots pine slightly increased compare with latest the years of the reporting period because the main damage on these species is mechanical damaging by humans on stem or natural branch clearing - natural branch dying from bottom up to top. Phytopatogens that endangered needles of coniferous are Dothistroma pini, or Chrysomixa abietis with this species.

Of all the trees assessed, $87 \%$ of the conifer, and approximately the same percentage of the broadleaves were not defoliated (leaves and needles). Only moderate defoliated (leaf or needle loss was more than $25 \%$ ) on sample trees of black pine. Without defoliation (absent or bitten there were 91\% in Scots pine, 94\% in spruce, and $95.5 \%$ in fir, respectively.

Looking at the observed period from May to September, it can be concluded that the data for defoliation with conifers and deciduous trees were fairly balanced. With coniferous and deciduous trees condition in 2020 set aside as the most unfavorable, for branches of small diameters manifested by lower defoliation on unaffected trees. In conifers, the situation was slightly better, while the deciduous was similar. As defoliation is leaves concerned, the only real legitimacy is evident in the strong defoliation of conifers, however, and it is difficult to talk about the trend because of the very small number of trees affected by this category of damage (total number is 10 trees). In the observed period, F.moesiaca was the most resistant species; on the many sample plots, no signs (absent or bitten leaves) of the defoliation were detected, whereas the weak defoliation of the trees was identified. Oaks are the most susceptible to foliage loss, most notably sessile oak, with twothirds of trees with moderate and weak leaves waste. The situation in the observed period was similar to the condition from the previous years, regarding $Q$. cerris and $Q$. fraineto. The Slight leaves waste of the coniferous trees was present on the spruce trees; a great number of trees were without the visible signs of this process. Fir is more vulnerable regarding decissation. Two-thirds of the observed trees of this species were with no defoliation at all, whereas the loss of the needles of the weak and moderate-intensity was identified on the other trees. The presence of the damage on the observed broadleaf trees is connected with the assessment of discoloration and defoliation. The parameters of this category and their values are close, i.e. they are approximately in the middle between the above-discussed percentages of these two processes. The phenology of the observed species, i.e. leaf rejection in the autumn, makes the broadleaves superior from this aspect. Beech was the most resistant species, these trees on all sample plots were without any damage. Spruce is the most vital conifer species, without any damage. It is followed by fir with $85.5 \%$ of trees without defoliation. During the 2020 droughts that caused the drying sessile oak forests in the mountain, regions assumed serious proportions; more and 
approximately $20 \%$ of affected trees. As the main reason for the drying indicated a significant decrease in soil moisture content due to an increase in temperature and a decrease in rainfall. The incidence of increased temperature during the vegetation period and frequent dry vegetation periods were the cause of weakening these forests. Conditions formed by these micro-climate changes were the main movers and intensive local factors for gradation of plant pests (pest moths and damaging epidemics of oak powdery mildew) - just about the phenomenon of indirect impacts of climate change on forest extinction (Chiru \& Chira 1998; Halmschlager 1998).

Despite the relatively small changes in foliage loss in the whole data, marked spatial and temporal variations in branches of different diameters existed during the study period. The endangered twigs in 2020 were highest in northern, central, and eastern Serbia. The highest endangered twigs values were found in the centraleastern part of the country. The endangered twigs of all sample trees was simmilar, highest in northern Vojvodina and scattered across the country. The highest values were found in the easternmost parts of Serbia in the observed period. The endangered twigs of the assessed trees seem to have intensified in 2020 in the easternmost parts of the country, as compared to a more diffuse pattern previously.

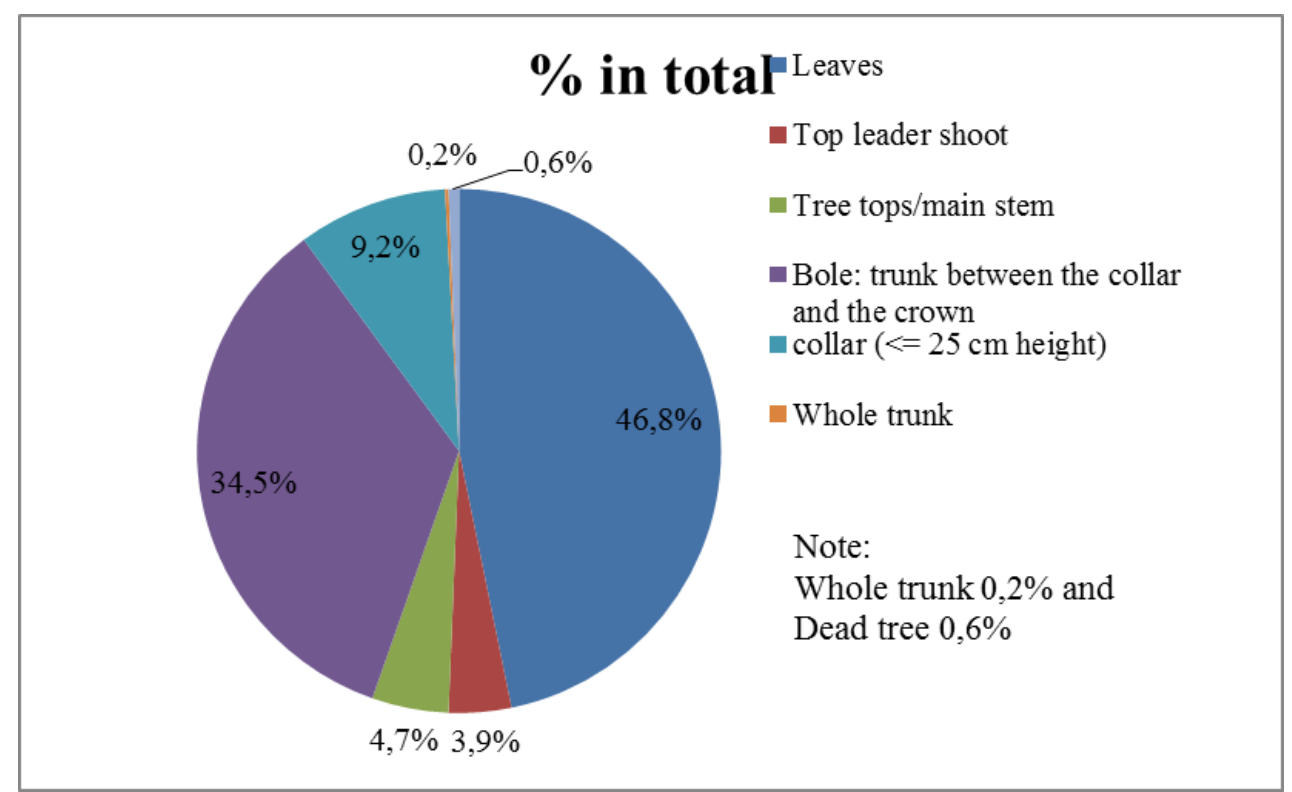

\section{Chart 1. Percentage of host plant parts damaged, presented from root to assimilation tissue}

Besides leaves and small $(46,8 \%)$ branches, the most endangered tree part was the stem or main bole (trunk between the collar) and the crown tree part with mechanical or central decay as a reason are the most represented (34,5). After those, there are collar injuries (root or decay and mechanical wound-9,2\%). After that comes with 4,7\% treetops (broken) and top leader shots (also refract on 3,9).

The whole trunk is destroyed and almost dead with $0,2 \%$ of the whole observed tree in the sample (Chart 1).

A dead tree is represented with $0,6 \%$ in the whole number of trees examed. 


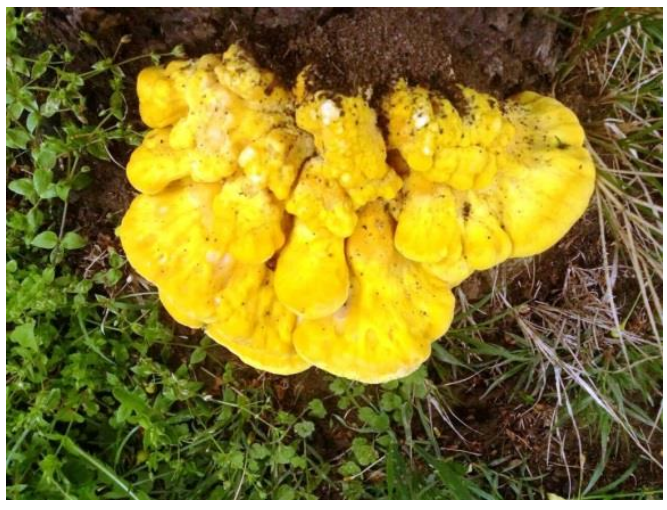

Picture 1. Laetiporus sulphureus,(Bull.) Murrill (1920), on a wild cherry, FMU Uzice, wood-decay fungus

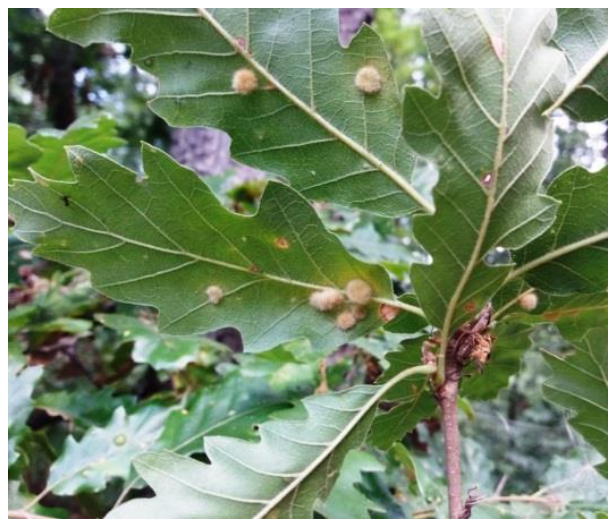

Picture 2. Cynipidae, Neuroterus Quercus baccarum L. on Turkey oak, FMU Boljevac, galls on leaves

\section{DISCUSSION}

Forests with their sustainable management today present one of the many principal international and national policy issues. To be sustainable, forest management requires information on the factors that affect forest health per vitality, biodiversity, and ecosystem functioning status. To date, numerous studies have assessed the impact and the importance of shaping of defoliation has received renewed scientific attention, on ICP extensive level (Ferretti et al, 1999; Nevalainen et al, 2010). Tree species-specific effects are regulated by mechanisms allowing for resistance to defoliating. The short-term consequences of leaf or needle loss depend on species abilities to resist many factors, and to recover after, and on competitive interactions between species. Although the abundance of many species generally decreases during the process so some taxa may increase in number during the observed period or shortly after. The most common effects or occurrence of assimilation organs rejection must be evaluated in the wider context of global climate and habitat change (Nevenić et al, 2011) - not just pests and plant diseases (Picture 1. и 2.). Considering the predicted increase in defoliation frequency and intensity (UNECE, 2004), interdisciplinary research initiatives on this issue are needed urgently. Our results suggest that extensive monitoring networks can reveal useful information about the widespread outbreaks of pest organisms (insects and fungi) already in their increased phases, giving some time for management decisions (Edgar \& Burk, 2006). In a changing climate, large-scale, regular monitoring of tree health, including abiotic and biotic causes, is more important than ever before. Biotic and abiotic - both kinds of factors in conjunction with climate and meteorological factors act on the root, collar, trunk, branches in the canopy (their drying), then twigs, and of course on assimilation tissue. Altogether, it causes a whole series of specific symptoms that affect the organs of trees. All of them appeared in 2020 in a certain percentage of all trees (Chart 2). 


\section{Percentage share of certain specific symptoms in the number of damaged trees}

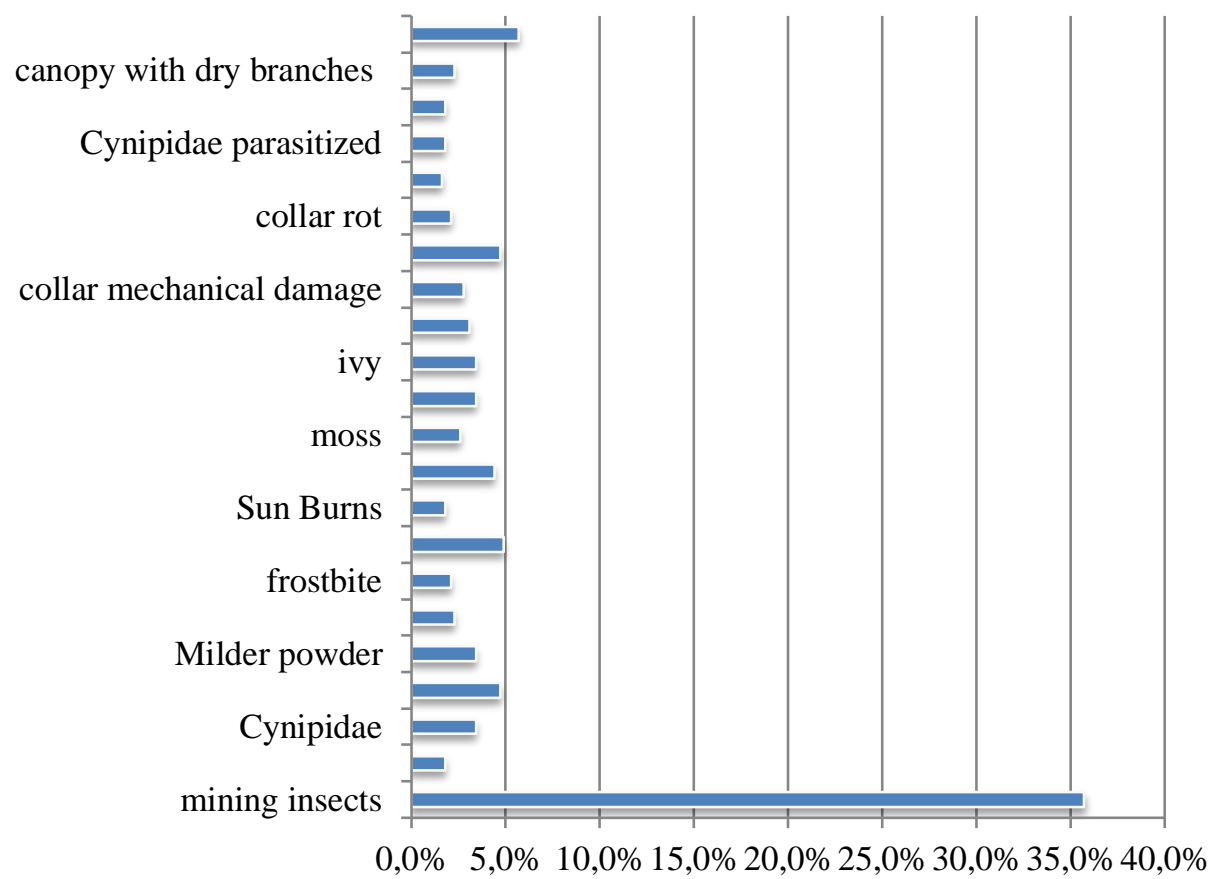

- Percentage share of certain specific symptoms in the number of damaged trees

Chart 2. Percentage of host plant parts damaged with obvious specific symptoms on which they occur

\section{CONCLUSION}

The frequency of damaged different endangered tree part is thought to be the main driver of vegetation dynamics in Serbia and its temperate forests according to ICP extensive sampling. The decline of oak forests has been linked to the detrimental effects of recurrent droughts, but before of destroyed assimilation tissue due to various symptoms.

Fieldwork on data collection (observations and measurements), in the previous period, was carried out in the period June - September in the year 2020.

In deciduous forests, beech and hornbeam are proven to be the most resistant species, in a process of leaves lost than oaks. Sessile oak was the most endangered species among the broadleaved. Among the coniferous trees, spruce proved to be a resilient species, while the black pine trees were far the most vulnerable to these processes of all registered species on sample plots.

The presented study is a baseline for the monitoring of changes in forest conditions and connectivity of these results with other indicators of environmental parameters and trees affected parts. It will provide more specific information, and 
making conclusions about the vitality of plants depending on environmental conditions. In the end, all comes to a final conclusion:

Leaf or needle loss is certainly are a widely underestimated ecological stress and selection forcefully exerted to forest ecosystems in Serbia. The other organs or the symptoms on them can not be ignored. Our observations have revealed several issues that should have priority in future research, such as:

1. Environmental factors. Variations of factors such as damage intensity, duration and return frequency, species-specific phenotypic plasticity, adaptive potential, and phylogenetic and physiological constraints must be experimentally identified concerning environmental events. This should lead to a concise classification of species and their organs according to their sensitivity with exactly environmental features linked to. Particular focus must be on vulnerable species and ecosystems because these will probably be the first to be seriously affected by the appearance of a recognized problem in progress.

2. The continuity. Long-term monitoring programs should be continued or developed since these are the only way for evaluating the impact of affected trees part as events on ecosystems. However, these programs should be coupled with integrative experimental and modeling approaches to enhance our understanding of complex plant organs drought and loss effects.

3. Idioeclogical dimension. The impact of affected trees part on ecosystem processes must be studied to better understand how it alters ecological functions and how these effects are influenced by species composition. All should help to define an indicator system for predicting drought sensitivity at the stand and forest levels.

3. Clarifying the causal and consequential relationship. Future research should focus on the simultaneous effects of different factors as causes, such as pests, forest management, pollution, and global warming. This is essential for identifying the most relevant factors that mediate the impact of damage as events on forest biodiversity.

4. Prevention of gain losses in wood production. The impact of strategies that are being proposed to mitigate the effects of leaf or needle loss, as other plant parts on trees on forest biodiversity should be rapidly evaluated, especially where the impact of the occurrence leads to yield reduction.

4. Biodiversity. The effects of defoliation events on forest biodiversity should be considered in both planning (e.g. tree species selection) and management (e.g. retention of deadwood).

*ACKNOWLEDGEMENTS:The study was carried out within the Projects:

1. Assessment and monitoring of the impact of air pollution and its effects on the forest ecosystems in the Republic of Serbia without AP Vojvodina in 2015 (Level I) and implementing intensive monitoring (Level II) at locations which are located in the area of PE "Kopaonik" Management Unit "Samokovska Reka", Srbijašume, PE "Uzice" Management Unit "Mokra Gora - Panjak", PE "Timocke Sume” Boljevac, Management Unit "Crni Vrh", financed by the Directorate of Forests, Ministry for Agriculture and Environment Protection of the Republic of Serbia;

2. Project TP-31070: "The Development of Technological Methods in Forestry in order to Attain Optimal Forest Cover", financed by the Ministry of Education and Science of the Republic of Serbia. 


\section{REFERENCES}

Chira, D. \& Chira, F. (1998): Beech problem in Romania, In: Proceedings of a workshop of IUFRO working party 07.02.06., Disease / environment interaction in forest decline. 23-29. Vienna

Edgar, C. B. \& Burk, T. E. (2006): A simulation study to assess the sensitivity of a forest health monitoring network to outbreaks of defoliating insects. Environmental Monitoring and Assessment, 122, 289-307.

Eichhorn, J., Roskams, P., Ferretti, M., Mues, V., Szepesi, A. \& Durrant, D. (2010): Visual assessment of crown condition and damaging agents. In UNECE (Ed.), Manual on methods and criteria for harmonized sampling, assessment, monitoring and analysis of the effects of air pollution on forests (pp. 49). Hamburg, Germany: UNECE, ICP Forests Programme Coordinating Centre.

Elzinga, C., Salzer, D. W., Willoughby, J.W. \& Gibbs, J.P. (2001): Monitoring plant and animal populations. MaIden: Blackwell Science, Inc.

Ferretti, M. (1997): Forest health assessment and monitoring - Issues for consideration. Environmental Monitoring and Assessment, 48, 45-72.

Ferretti, M. (1998): Potential and limitation of visual indices of tree condition. Chemosphere, 36(4-5), 1031-1036.

Ferretti, M., Bussotti, F., Cenni, E., \& Cozzi, A. (1999): Implementation of quality assurance procedures in the Italian programs of forest condition monitoring. Water, Air, and Soil Pollution, 116, 371-376.

Ferretti, M. (2004): Forest health diagnosis, monitoring and evaluation. In J. Burley, J. Evans, \& J. Youngquist (Eds.), Encyclopedia of forest sciences (pp. 285-299). London: Elsevier Science.

Ferretti, M. \& Chiarucci, A. (2003): Design concepts adopted in long-term forest monitoring programs in Europe problems for the future? Science of the Total Environment, 310, 171178.

Ferretti, M., Fischer, R., Mues, V., Granke, O. \& Lorenz, M. (2010a): Basic design principles for the ICP Forests Monitoring Networks. Manual Part II, 22 pp. In Manual on methods and criteria for harmonized sampling assessment, monitoring and analysis of the effects of air pollution on forests. UNECEICP Forests Programme Co-ordinating Centre, Hamburg. http:// www.icp-forests.org/Manual.htm. Accessed 2 May 2014.

Ferretti, M., König, N. \& Granke, O. (2010b): Quality assurance within the ICP Forests monitoring programme. Manual Part III, $11 \mathrm{pp}$. In Manual on methods and criteria for harmonized sampling, assessment, monitoring and analysis of the effects of air pollution on forests. UNECE ICP Forests Programme Co-ordinating Centre, Hamburg. http://www. icpforests.org/Manual.htm. Accessed 20 May 2014. 
FOREST EUROPE, UNECE and FAO (2011). State of Europe's forests 2011. Status and trends in sustainable forest management in Europe. Ministerial Conference on the Protection of Forests in Europe, FOREST EUROPE Liaison Unit Oslo, pp 336.

Innes, J. L. (1993): Forest health: its assessment and status, Wallingford: Can International.

Innes, J. L, Landmann, G. \& Mettendorf, B. (1993): Consistency of observations of forest tree defoliation in three European countries. Environmental Monitoring and Assessment, 25, $29-40$.

Halmschlager, E. (1998): The possible role of Armillaria spp. and Phytophthora spp. in the oak decline complex. Iz: Proceedings of a workshop of IUFRO working party 7. 02.06, Disease / environment interaction in forest decline. 49-56. Vienna.

Mihajlović, Lj. (2008): Šumarska entomologija, Šumarski fakultet, Beograd.

Nevalainen, S., Lindgren, M., Pouttu, A., Heinonen, J., Hongisto, M., Neuvonen, S. (2010): Extensive tree health monitoring networks are useful in revealing the impacts of widespread biotic damage in boreal forests, Environmental Monitoring and Assessment, Volume 168, Issue.

Nevenic, R. and a group of authors (2008): Praćenje stanja šuma u Republici Srbiji prema programu ICP za šume (International Cooperation Programme for Forest Monitoring ) i konvenciji CLRTAP (Convention on Long Range Transboundary Air Pollution) Annual Report ICP Forests 2008 Level I. Institute of Forestry, Belgrade. pp 15 ISSN: 1452-8576

Nevenic, R. (2008): GIS as a Tool in Forest monitoring in Serbia in a frame of ICP Forest Monitoring Programme. Symposium of Computer and Informatical Technologies YU INFO 2008. Kopaonik, Serbia. Proceedings, pp. 284-287. ISBN 978-85525-03-02.

Nevenić, R., Tabaković-Tošić, M., Rakonjac, Lj. (2009): Neki pokazatelji vitalnosti šuma Republike Srbije, Monografija, Institut za šumarstvo, Beograd.

Nevenić, R., Rakonjac, Lj., Orlović, S. (2011): Praćenje i procena uticaja zagađenja vazduha i njegovih efekata u šumskim ekosistemima na teritoriji Republike Srbije - monitoring stanja šuma, Nivo I i Nivo II, Monografija, Institut za šumarstvo, Beograd.

***** (2012) Procena i praćenje efekata - uticaja vazdušnih zagađenja na šumske ekosisteme u Republici Srbiji, Institut za šumarstvo, Beograd.

Redfern, D.B. \& Boswell, R.C. (2004): Assessment of crown condition in forest trees: comparison of methods, sources of variation and observer bias. Forest Ecology and Management, 188, 149-160.

Seidling, W., \& Mues, V. (2005): Statistical and geostatistical modelling of preliminarily adjusted defoliation on an European scale. Environmental Monitoring and Assessment, 101, 223-247.

Solberg, S. \& Strand, L. (1999): Crown density assessments, control surveys and reproducibility. Environmental Monitoring and Assessment, 56, 75-86. 
Tabaković-Tošić, M., Marković, M. (2004): The influence of phytophagous insects on the health status of coppice beech forests of eastern Serbia. Collected Works, Collection Tom 50-51. Institute of Forestry, Belgrade, p. 56.

Mihajlović, Lj. (2008): Forest Entomology, Textbook, Publ. Faculty of Forestry, Belgrade, ISBN 978-86-7299-152-9, p. 499.

Karadžić, D. (2010): Forest Phytopathology, Textbook, Publisher: Faculty of Forestry, Belgrade Faculty of Forestry, Banja Luka, ISBN 978-86-7299-177-2, p. 330.

Stefanović, T., Nevenić, R., Bilibajkić, S., Marković, N. (2003): Istraživanje i ocena praćenja efekata vazdušnih zagađenja na šume u okviru Programa EU - ICP Forests. Zbornik radova, Institut za šumarstvo, Tom 48-49, Beograd, str. 79-87.

Travaglini, D., Fattorini, L., Barbati, A., Bottalico, B., Corona, P., Ferretti, M., Chirici, G. (2013): Towards a sampling strategy for the assessment of forest condition at European level: combining country estimates Environmental Monitoring and Assessment, Volume 185, Issue 4, p 3255-3268.

UNECE (2004) Manual on methodologies and criteria for modelling and mapping critical loads and levels and air pollution effects, risks and trends. Retrieved from http://www.icpmapping.org 6 May 2014.

UNECE (2010) Manual on methods and criteria for harmonized sampling, assessment, monitoring and analysis of the effects of air pollution on forests. Hamburg, Germany: UNECE, ICP Forests Programme Co-ordinating Centre. http://www.icpforests.org/Manual.htm Accessed 27 May 2014.

UNECE (2011) http://www.icp-forests.org/ Accessed 25 May 2014

\title{
FOREST ECOSYSTEMS VITALITY MONITORING (ICP FORESTS, LEVEL I) WITH SPECIAL EMPHASIS TO THE AFFECTED PART OF THE SAMPLE TREES IN THE REPUBLIC OF SERBIA
}

\author{
Renata GAGIĆ-SERDAR, Tomislav STEFANOVIĆ, Ilija ĐORĐEVIĆ, \\ Goran ČE $\check{L} L A R$, Miroslava MARKOVIĆ, Natalija MOMIROVIĆ
}

\section{Summary}

Forest Condition Monitoring, Level I, refers primarily to the monitoring and assessment of defoliation of tree crowns on the installed sample plots. The condition of forests was monitored in 2020, but with special emphasis on parts of the tree with damage, on about 130 sample plots in the Republic of Serbia, like every year.

The National Focus Center for Forest Monitoring in the Republic of Serbia, within The Institute of Forestry, actively participates in the international ICP Forest programme, improving its approaches in order to monitor synchronized work.

The paper presents damages as indicators of forest vitality, but they are presented through the affected parts of damaged trees. Their appearance shows a certain regularity and could be interpreted as a trend.

The degree of tree crown damage and entire trees on leaves and conifers were researched on about 130 permanent experimental plots in the Republic of Serbia in 2020. The 
defoliation was assessed at 5\%. The sample plots are systematically distributed in a $16 \times 16$ $\mathrm{km}$ or $4 \mathrm{x} 4 \mathrm{~km}$ grid system.

The damage is presented as a percentage of the total damaged trees in Serbia. The results show which main factors cause damage to parts of the tree of deciduous and coniferous species. Within the study of the impact of regional climate change on forest communities, a better insight into the effects of damaged parts of trees, harmful trends, as well as the present forests' health state in Serbia will be provided.

\title{
MONITORING VITALNOSTI ŠUMSKIH EKOSISTEMA (ICP ŠUME, NIVO I) SA POSEBNIM OSVRTOM NA OŠTEĆENI DEO STABLA U REPUBLICI SRBIJI
}

\author{
Renata GAGIĆ-SERDAR, Tomislav STEFANOVIĆ, Ilija ĐORĐEVIĆ, \\ Goran ČE ̌́LJAR, Miroslava MARKOVIĆ, Natalija MOMIROVIĆ
}

\section{Rezime}

Praćenje stanja šuma, Nivo I, odnosi se prvenstveno na praćenje i procenu defolijacije krošnji drveća na stalnim oglednim parcelama. Kao i svake godine u 2020. godini izvršen je monitoring stanja šuma, ali sa posebnim naglaskom na delove stabla sa oštećenjima, na oko 130 oglednih površina u Republici Srbiji.

Nacionalni fokusni centar za monitoring šuma u Republici Srbiji, u okviru Instituta za šumarstvo, aktivno učestvuje u međunarodnom programu ICP šume poboljšavajući svoje pristupe u cilju praćenja sinhronizovanog rada.

U radu su prikazane štete kao pokazatelji vitalnosti šuma, ali su one prikazane i kroz pogođene delove oštećenih stabala. Njihova pojava pokazuje određenu pravilnost i mogla bi se protumačiti kao trend.

Stepen oštećenja krošnji i celog drveća na lišću i četinama istražen je na oko 130 stalnih oglednih površina u Republici Srbiji u 2020. godini. Defolijacija je procenjena 5\%. Ogledne površine su sistematično raspoređene u mrežni sistem 16x16 km ili 4 x 4 km.

Šteta je prikazana u procentima od ukupnog broj oštećenih stabala u Srbiji. Rezultati pokazuju koji glavni faktori izazivaju oštećenja na delovima stabla lišćarskih i četinarskih vrsta. U okviru proučavanja uticaja regionalnih klimatskih promena na šumske zajednice, pružiće se bolji uvid u efekte oštećenih delova stabala, štetni trendovi, kao i u trenutno zdravstveno stanje šuma u Srbiji. 